\title{
Environmental Policies and Sustainable Development in Transition Countries: Case Study of Albania
}

\author{
Dafina Nazaj \\ Faculty of Economics, European University of Tirana, Albania
}

Ermelinda Tolica (Corresponding author)

Faculty of Economics, Department of Business Administration, University of Vlora "Ismail

Qemali", Albania

E-mail: e_tolica@yahoo.com

Received: September 27, 2014 Accepted: October 10, 2014 Published: October 14, 2014

doi:10.5296/ijrd.v1i1.6448ＵRL: http://dx.doi.org/10.5296/ijrd.v1i1.6448

\begin{abstract}
The transition period has undoubtedly deserved, and it still does, in-depth analysis of the overall economy. Different studies in transition countries have served for the recognition of realities, taking action and policy development needed for economic development. Almost all transition countries are still undergoing a deep economic crisis. The nature of this crisis comes from a restructuring of the infrastructures created for a centralized economy.

Many countries have been concerned with the problems that the development has caused in the environmental aspect. Transition countries are faced even with greater environmental problems because of their need to be developed rapidly.

At low levels of development, both the quantity and the intensity of environmental degradation are limited to the impacts of subsistence economic activity on the resource base and to limited quantities of biodegradable wastes. As agriculture and resource extraction intensify and industrialization takes off, both resource depletion and waste generation accelerate.
\end{abstract}

From an environmental perspective a decline in GDP is positive if hazardous materials pollution reduced. However, if one wants to analyze the dynamics of release per unit of production these relations will grow along with GDP in almost all transition economies.

Economic situation in Albania, was very difficult due to the political instability of the country, which impede the development and implementation of a sustainable strategy and long-term 
economic reforms. Secondary data about economic growth and environmental indicators such as air pollution, water pollution and land pollution are analyzed for Albania as a country in transition. The figures follow the model of relationship between variables, relevant also to the choice of environmental policy instruments. The cost-effective policy becomes important in the case of Albania. Policies should also involve the population and make the necessary improvements .

Keywords: Transition countries, Economic growth, Environment, Policies

\section{Introduction}

Many countries are experiencing a situation of transition in their economic and political system, since the changes of centralized economy towards the market economy. The transition period has undoubtedly deserved, and it still does, in-depth analysis of the overall economy. These analyzes are conducted periodically by individuals, researchers and institutions associated with economic developments. These studies and analyses have served for the recognition of realities, taking action and policy development needed for economic development. Transition to a market economy is a lengthy process comprised of various spheres of economic activities. New institutional arrangements are of key importance for successful transformation (Karayel \& Çíftiçí).

Transition Economies pose specific problems in economic terms. Their past dictatorial structure differs completely in contrast to the free market economy. Macroeconomic standards that can be applied in a market economy cannot be applied in the transition economy because of its volatile nature. Transition economies have specific features that until recently were not previously known to scholars. These features influence the managers' responsibility for the economy. Their behavior differs between countries in transition and countries with a free market economy. It is therefore impossible for the application of environmental knowledge in the same manner as applied to the developed countries. One question that arises in this respect concerns the nature of entrepreneurship under transition conditions and the extent to which it is distinctive compared with mature market economies, in which external environmental conditions are likely to be more stable and where there is a stronger recent tradition and experience of entrepreneurial activity (Smallbone \& Welter, 2001, pp. 249).

Almost all transition countries are still undergoing a deep economic crisis. The nature of this crisis comes from a restructuring of the infrastructures created for a centralized economy. Their previous economic model was insufficient respect for sustainable development, which meant the controlled use of natural resources without major consequences to the environment. Actually, transition countries, where still belongs Albania have real opportunities for replacement of old structures with more "friendly" structures in relation to the environment. In this regard, the measurement of sustainable development is important to ensure that the proper economic and development policies can be undertaken especially from the environmental point of view. 


\subsection{Methodology}

Different indicators have been used from different projects and institutions, to measure their relative progress or lack of progress toward sustainable development. (KAtes et al. 2005 has studied these indicators referring to such initiatives as Commission on Sustainable Development, Consultative Group on Sustainable Development Indicators, wellbeing index, Environmental Sustainability Index, Environmental Sustainability Index, U.S. Interagency Working Group on Sustainable Development Indicators, Global Reporting, Boston Indicator Project Initiative, etc. (Kates et al 2005) few of the efforts are explicit about the time period in which sustainable development should be considered.

We have chosen some of the indicators according o the available data in the Statistical national institution of Albania, which deal with some of the initiatives mentioned above.

The indicators are listed in the table below. The relationship between the growth indicators such as GDP and value added in the economy and environmental indicators will be the focus to explain why some environmental policies are appropriate in the Albanian case.

\section{Economic Characteristics of Countries in Transition}

A characteristic of the transition countries is the crisis of investment due to lack of confidence. Enterprises do not have sufficient resources to invest. The banking system is still in an embryonic stage, and foreign investors are still unsure about investing in a developing economy. Moreover, transition countries are often faced with the budget deficit. Another characteristic of transition countries is the high level of inflation. Although this level has been reduced measures on the basis still remains high compared with developed countries. The high level of inflation reduces investor interest in the country, strengthening so another feature of the transition economies, which is known as high risk investments and low predisposition to technology innovation. Transition economies are characterized by high rates of discount have high discount rates which substantially affecting the behavior of those responsible for managing the economy. Environmental benefits are considered rare, and willingness to pay for environmental services is generally low. In a very short future horizon decision making for individuals and companies tends to diminish more and more. Society seems in many cases almost imperceptible in relation to government policies, which may have a negative environmental impact in the future.

The problem of distribution and exchange of information is deeper in the transition economies. Without information firms will have to pay large transactions costs. Yet the structure of the market is still developing, advertising culture is poor, transparency is low, and the information is not distributed in the same way as in developed countries. Lack of information significantly increases business costs and hides the real environmental costs. Lack of environmental information, can be balanced by investors who want to avoid unexpected legal problems in the future. Specific agencies or private companies can create an accurate baseline information on green technologies which will help entrepreneurs to allocate capital more efficiently. However this cannot happen if companies do not sign preliminary agreement on environmental protection that charge them with legal responsibility. 


\section{Environmental Policies and Sustainable Economic Development in Transition Countries}

Many countries have been concerned with the problems that the development has caused in the environmental aspect. Transition countries are faced even with greater environmental problems because of their need to be developed rapidly. In this context, questions regarding the relationship between economic growth and environmental problems are concerning policy makers and researchers, since sustainable development has been an important concept suggested by the latest. Relationship between goals of economic growth through sustainable development and environmental impacts is analyzed by different scientists.

The Brundtl and Commission's brief definition of sustainable development, which is one of the most mentioned about the subject, states that it is" the ability to make development sustainable - to ensure that it meets the needs of the present without compromising the ability of future generations to meet their own needs"( WCED 1987). The implication of economic growth and environment are explained later on, in the report which says that ...economic growth-but also equity to share resources with the poor-is required to sustain them. The report also speaks about the environment: The concept of sustainable development does imply limits-not absolute limits but limitations imposed by the present state of technology and social organization on environmental resources and by the ability of the biosphere to absorb the effects of human activities (WCED, 1987).

Growing economic activity (production and consumption) requires larger inputs of energy and material, and generates larger quantities of waste by-products. (Georgescu \& Roegen 1971) and Meadows et al., 1972) Increased extraction of natural resources, accumulation of waste and concentration of pollutants will therefore overwhelm the carrying capacity of the biosphere and result in the degradation of environmental quality and a decline in human welfare, despite rising incomes. (Daly 1991) It is also argued that the risk of economic activity will increase with the increases of the degradation of the resource base. So, the world must make a transition to a steady-state economy, to reach the today's goal to save the environment for the purpose of a sustainable development. On the other hand, there are others who say that the fastest road to environmental improvement is through economic growth: with higher incomes comes increased demand for goods and services that are less material intensive, as well as demand for improved environmental quality that leads to the adoption of environmental protection measures (Kates et al. 2005). As Beckerman puts it, "The strong correlation between incomes, and the extent to which environmental protection measures are adopted, demonstrates that in the longer run, the surest way to improve your environment is to become rich”(Beckerman 1992)

At low levels of development, both the quantity and the intensity of environmental degradation are limited to the impacts of subsistence economic activity on the resource base and to limited quantities of biodegradable wastes. As agriculture and resource extraction intensify and industrialization takes off, both resource depletion and waste generation accelerate.

From an environmental perspective a decline in GDP is positive if hazardous materials 
pollution reduced. However, if one wants to analyze the dynamics of release per unit of production these relations will grow along with GDP in almost all transition economies. The trend is dangerous because it always seeks economic growth accompanied by high levels of pollutants. At the same time, overall total increase, per unit pollution can decrease production. In short, correspondence between pollution and production units in most cases depends on the government's environmental policies.

Others (Shafik \& Bandyopadhyay) have hypothesized that the relationship between economic growth and environmental quality, whether positive or negative, is not fixed along a country's development path; indeed it may change sign from positive to negative as a country reaches a level of income at which people demand and afford more efficient infrastructure and a cleaner environment. The implied inverted-U relationship between environmental degradation and economic growth came to be known as the "environmental Kuznets curve," by analogy with the income- inequality relationship postulated by Kuznets.

Steedman (1997, p. 92) notes that there are two factors which suggest that there is a particularly important role for the application of economic instruments to air pollution control in the economies in transition. First, the magnitude of the costs required to meet environmental objectives, and the substantial competing claims for limited resources, suggest that governments might have to give more serious consideration to economic instruments than has been usual in Western Europe. Second, several countries, [...], already impose, or have the legislation to impose, emission fees and fines on polluters.

\subsection{Environment Policies}

Nations with economies in transition are likely to exhibit certain characteristics that are relevant to the choice of environmental policy instruments. First of all, the emerging market economies cannot afford the luxury of spending any more than necessary on environmental protection measures if they are simultaneously to achieve their broader economic and social goals (Stavins \& Òylicz 1994).

So, the cost-effective policy becomes important in this case. Competitive markets and entrepreneurship Leads to cost effective solutions more than in situations with strong centralized command and control. So, particular consideration should be given to potentially cost-effective, market-based environmental policy instruments. Pollution reduction targets are ambitious throughout Central and Eastern Europe. The Helsinki Protocol (to the Convention of Long-Range Trans boundary Air Pollution), is signed by most of the countries, requiring 30 percent SO2 emission reductions (with respect to a 1980 baseline) by 1993. Most countries have met this target, although largely as a consequence of production declines. Permanent reductions by larger amounts, will require additional effort.

\section{The Situation in a Transition Country as Albania, The Case Study}

In order to have a synthetic overview of the evolution of the economic situation in Albania during the period 1990 - 2000, it is necessary to be recognized, the basic features of the Albanian economy in the wake of the 90's. The long period of self-isolation that Albania experienced the socialist system, coupled with a discretionary economic policy of autarkic 
tendency, led to the creation of an unbalanced structure, backward and conservative, who rely on absolute rule of social ownership and centralized management by the state. For this reason, anyone who examines the growth rates of the Albanian economy for the period from 1951 to 1990, notes that they fall continuously every five years. This is a result of resource exhaustion of extensive growth. Investment increase fell by the 70', reaching the lowest level in the period 1986-1990, combined with the structural crisis in the 80', associated with a bad economic situation of rationing food products, increasing inflation and unemployment, the stagnation and then decline in real income per capita.

Economic situation was very difficult due to the political instability of the country, which impede the development and implementation of a sustainable strategy and long-term economic reforms. Government out of pluralist elections of 1992 undertook a broad liberal economic reform, improvised and highlighting elements of shock therapy (Kolodoko, 1992). This policy caused a deep depression in industrial production, which continued until the end of 1994 and end of 1996, it seemed a new deterioration of the economic situation of the country. With the start of 1997, these trends were increasingly added, bringing the country to a new economic collapse and social explosion that marked the second mate of the Albanian economy. The most notable aspect of this crisis is the collapse of informal financial institutions that began at the end of November 1996 These institutions lie on the territory of Albania and had accumulated over a period of 2-4 years savings of over one third of the total number of Albanian families, which are estimated at about 1.2 billion USD. In March 1999 the Albanian economy suffered a shock third by the arrival of about 500,000 refugees from Kosovo. Country's fragile infrastructure was weakened further by the unexpected influx of population. Another characteristic of economic transition in Albania is that domestic consumption is greater than production, while the difference is covered by private transfers Albanian immigration and international aid organizations. From 1991 until the end of 1999 Albania had substantial foreign aid from the European Community. While shipments of Albanian emigration during the years 1991 - 2000, as an annual average, have been about 400 to 450 million USD (Note 1 ).

The recovery of the economy in order to succeed the level of 1990, begun only after the year 2003 (Kota 2009).The growth rate of real GDP for 1998 pointed to 8.6 percent, growing higher for the ongoing years and stabilizing during 2001-2002, at an average rate of 6.5 percent. During the economic crisis of 2002, economy grew only by 4.3 percent. In the meantime, starting from 2003, the average annual growth pointed to 6 percent. After the annual growth rate of $7.85 \%$ in 2008, the global financial crisis was reflected on the slowing down of the economic growth recording only $3.3 \%$ in 2009 (Kota, 2009).

Albania's merchandise export sheld up especially well in 2012, but the value of services export fell and overall, it was the decline in imports in the wake of feeble domestic demand that contributed most to a noticeable reduction in the current account deficit (3).

From the perspective of financial flows injection, compared with other transition economies of central and eastern Europe, as a result of the small size and huge immigration, Albania is the only country in this aspect resembles East Germany. Ten years after the implementation 
of this policy, in 2000 inflation fell to 3 per cent, budget deficit at 9.6 percent, the exchange rate has been quite stable over the last three years, while the annual growth after 1997 was about 8 percent. These achievements undoubtedly constitute an Albanian transition relative success. But, if they would use some other evaluation criteria, much wider than those in question, we see that industrial production has not yet reached the level of 1989, the trade balance deficit is growing, despite the export dynamics, while massive unemployment remains high. All these phenomena are associated with profound changes in the structure of GDP. The main branch of industry, which in 1989 gave 41.3 percent of GDP, currently provides only 12 percent of it. While agriculture went from 35.5 percent in 1990 to 52.3 percent in 1999 economic structure passed by a dis-equilibrium in the other. New imbalance appeared in the regional development of the country, in the aftermath of the crisis and uneven economic development. 70 percent of foreign direct investments are concentrated in the axis Tirana - Durres, while the rest of them, in the western and southern areas of the country. Foreign direct investment and the creation of new enterprises by domestic capital, have been the main factor that determined the creation of new jobs, income level of the population, the pace of economic and social development by districts (Note 2).

The transition to a market economy has been accompanied by the reorganization of whole sectors of the economy. The restructuring of large state enterprises helped create a number of smaller private enterprises. New opportunities to develop free private enterprise participation increased substantially different entities and private individuals in the economy, contributing to the emergence of the private sector.

The secondary data gathered for the last 5 years in Albania about the GDP, Value added in the economy on one hand and environment indicators on the other hand, are shown in table 1. After studying the situation of Albania and all the possible indicators on environment, three indicators are chosen because of their relationship with the most important development sectors and what they affect in the environment in Albania.

PM10 particles which are the fraction of particulates in air of very small size $(<10 \mu \mathrm{m})$ and PM2.5 particles $(<2.5 \mu \mathrm{m})$ are of major current concern because of their impact in human health, posing great risks. Since the principal source of airborne PM10 and PM2.5 is road traffic emissions, particularly from diesel vehicles and in Albania there is a problem with old vehicles and with the lack of control of the emissions, this indicator is very important to be studied. As it can be seen by the data, the average figures have been changing over time, being around 90, but only in 2012 this figure has fallen below average.

Urban wastes are also an important indicator due to lack of attention to this problem in the past two decades. In Albania there is a lack of methods for reducing urban waste. While the EU countries, efforts are numerous, in Albania there is lack even of landfills, which are not one of the best methods for reducing the effects of urban waste on the environment.

Inert wastes are chosen because the most important industry in the country has been the construction industry, but only in the last two years it has decreased in sales and profits. Also, the construction process is carried out without applying standards, posed by the low, in some cases even the law is not sufficient to take appropriate measures to safeguard the environment, 
in this industry.

Table 1. Economic and environment indicators in Albania. Source INSTAT

\begin{tabular}{|c|c|r|r|r|r|r|}
\hline \multicolumn{3}{|c|}{ Indicator } & 2008 & 2009 & 2010 & 2011 \\
\hline \multirow{3}{*}{ Economic growth } & $\begin{array}{c}\text { Tremester gross } \\
\text { value-added with } \\
\text { current prices }\end{array}$ & 936917 & 989796 & 1077485 & 1131121 & 1157377 \\
\cline { 2 - 7 } & GDP(000 leke) & 319964832 & $326,422,609$ & $402,140,912$ & $442,390,000$ & $464,372,369$ \\
\hline \multirow{3}{*}{ Environment Indicators } & Avg PM10 & 92.3 & 85.6 & 89.2 & 90.7 & 56.6 \\
\cline { 2 - 8 } & Inert wastes & 455866 & 455866 & 326805 & 712933 & 332199 \\
\cline { 2 - 8 } & Urban wastes & 762353 & 857223 & 1069094 & 1077997 & 1136802 \\
\hline
\end{tabular}

From an environmental perspective a decline in GDP is positive if hazardous materials pollution reduced. However, if one wants to analyze the dynamics of release per unit of production these relations will grow along with GDP in almost all transition economies. In fact, this is shown also in graph 1 and 2, where all the growth and environmental indicators are presented together. Raise in gross value added and in GDP are associated with same trend in urban wastes. Inert wastes, on the other hand, have fallen recently in 2012, probably because of the decrease of the construction industry, while PM10 is approximately constant, decreasing only in 2012 (it is not very visible, because of the low values comparing to other indicators).

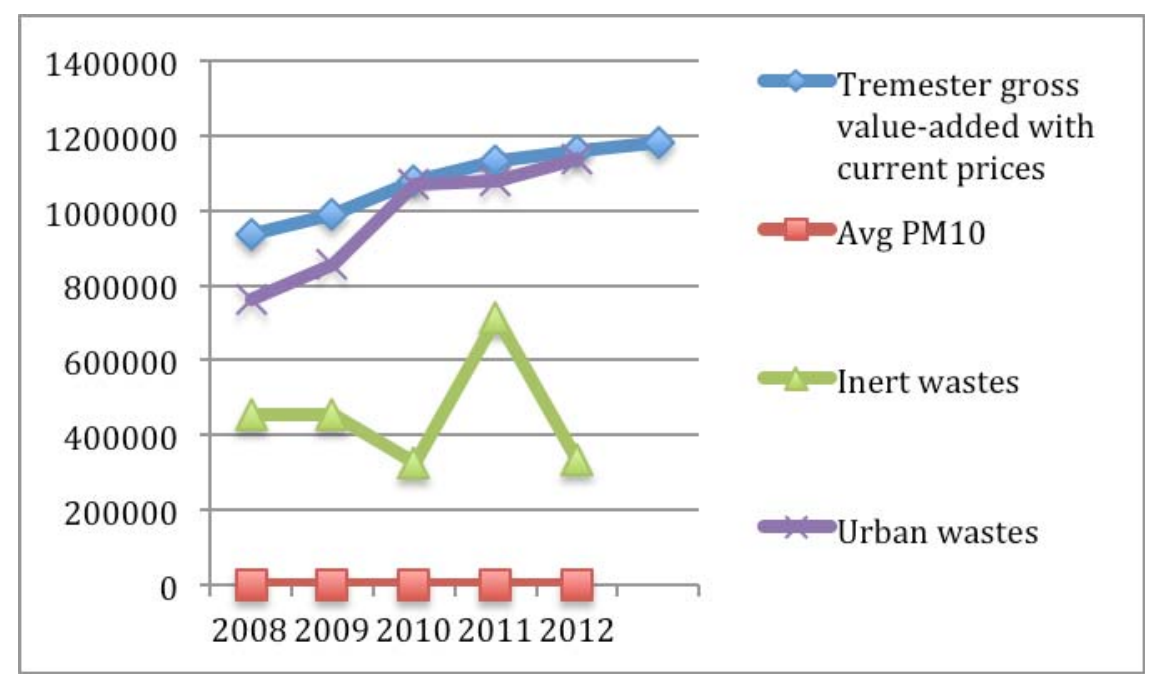

Figure 1. Value-added in the economy and the environment indicators 


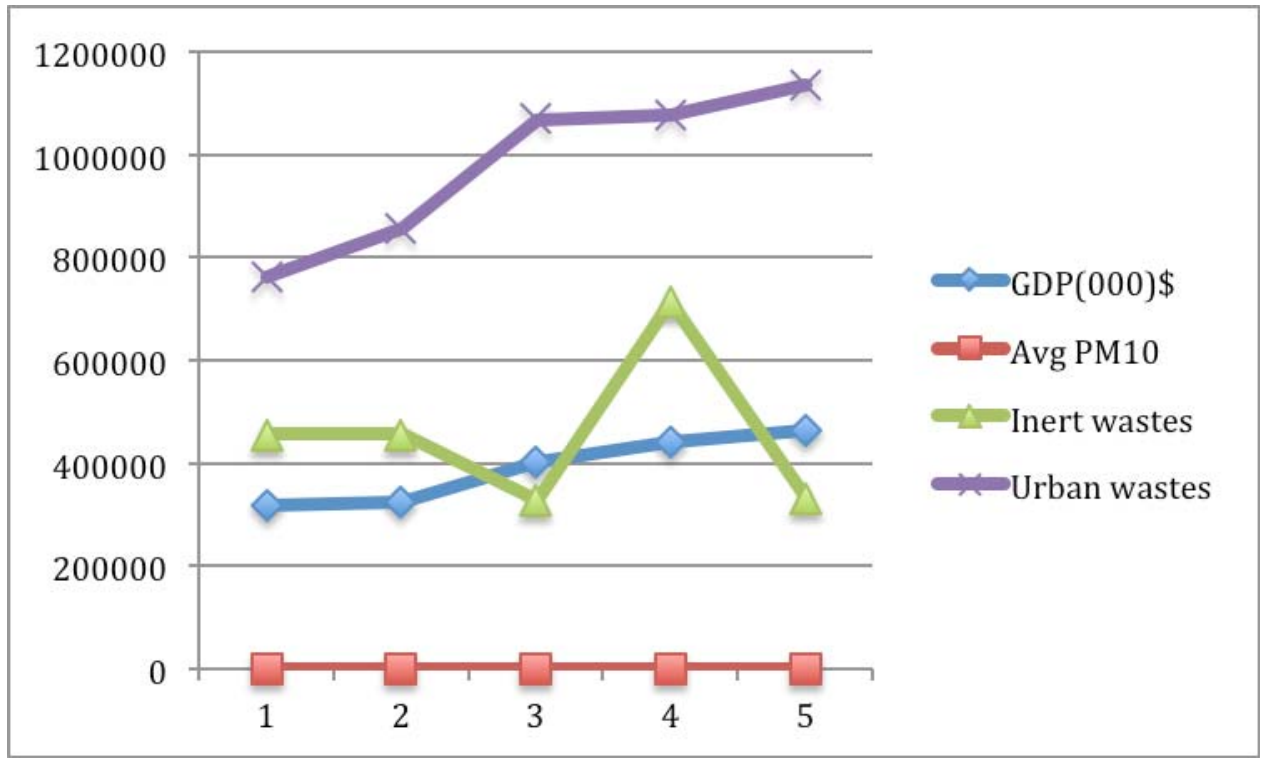

Figure 2. Relationship of environment indicators with GDP

\section{Conclusion and Future Research}

Economies in transition countries have faced different economic challenges during their phases of transition in the market economy. These issues are related to economic growth, the welfare of their societies such as inflation and unemployment, financial issues such as debt and interest rates, etc. One of these issues is also related with the environment protection during the efforts for economic growth.

Transition countries have recently understood that sustainable development is the right way of development, and for achieving sustainable development goals, environmental policies are important for future generations.

Many transition countries have experienced problems with environment because of their lack of policies in this respect. Policy makers must take into account the impact of environmental policies on economic growth, as well as the impact of economic growth on environmental aspects, because it is a two-way street. In developing countries the cost-effective policies on the environment become important.

Albania as a country in transition in the last 20 years has experienced a lot of problems with its sustainable development, although in terms of growth it has performed well, in general. But indicators of environment have deteriorated, except for the last years. Data show that in some cases, growth in the economy goes with the same trend as environment problems, but in others, there are changes in this trend. From the point of view of environment policies we can not say based on the data that the right policies have impacted the decrease in air pollution or inert wastes, because during this year, have not been undertaken different policies. Anyway, time is a serious constraint in this regard because data about air and water pollution and different types of wastes are sometimes missing for a long period, more than 5-7 years. 
But high level of air pollution and also water polluted areas need serious action with effective policies to safeguard especially hot-spot areas. Policies for reducing urban wastes are also most important than others, because of the lack of application of methods of recycling or others.

Future research can make comparisons with other transition countries to show direct or indirect relationship between environmental policies and economic growth, as well as to show the effectiveness of these policies.

\section{References}

Beckerman, W. (1992). Economic growth and the environment: whose growth? Whose environment? World Development, 20(1), 481-496, http://dx.doi.org/10.1016/0305-750X(92)90038-W

Daly, H. (1991). Steady-state Economics (San Francisco, Freeman \& Co., 1977) (2nd ed.) Washington, D.C.: Island Press.

Georgescu-Roegen, N. (1971). The Entropy Law and the Economic Process. Cambridge: Harvard University Press.

Karayel, M. (nd). Entrepreneurship in transition economies: A literature review of the Central and Eastern European Countries. Retrieved from http://ces.epoka.edu.al/icme/Entre_Trans_Eco_CEEC_MK_MC.pdf

Kolodoko, G. E. (1992). Stabilisation, récession et croissance dans les economies postsocialistes. Economie prospective internationale, 51, 17.

Kuznets, S. (1966). Economic Growth and Structural Change. Modern Economic Growth New Haven: Yale University Press.

Meadows, D. H., Meadows, D. L., Randers, J., \& Behrens, W. (1972). The Limits to Growth. London: Earth Island Limited.

Robert, W. K., Thomas, M. P., \& Anthony, A. L. (2005). Environment: Science and Policy for Sustainable Development.

Shafik, N., \& Bandyopadhyay, S., (1992). Economic Growth and Environmental Quality: Time-Series and Cross-Country Evidence. World Bank Policy Research. Working Paper, No. 904 (Washington, D.C.),

Smallbone, D., \& Welter, F. (2001). The Distinctiveness of Entrepreneurship in Transition Economies. Small Business Economics, 16, 249-262. http://dx.doi.org/10.1023/A:1011159216578

Stavins, R. N., \& Òylicz, T. (nd). Environmental policy in a transition economy, designing trade permits for Poland. Discussion Paper E-95-01, Kennedy School of Government, Harvard University. Retrieved from http://belfercenter.ksg.harvard.edu/publication/2823/environmental_policy_in_transition_eco nomy.html 


\section{Macrothink}

International Journal of Regional Development

ISSN 2373-9851

2014, Vol. 1, No. 1

Stern, N. (1998). The Future of the Economic Transition. EBRD Working Paper, No 30.

World Commission on Environment and Development (WCED). (1987). Our Common Future. New York: Oxford University Press.

\section{Notes}

Note 1. Instat. Retrieved from http://www.instat.gov.al

Note 2. Samson I., Albania experience among transition trajectories, Working Paper, Grenoble 1996.

\section{Copyright Disclaimer}

Copyright for this article is retained by the author(s), with first publication rights granted to the journal.

This is an open-access article distributed under the terms and conditions of the Creative Commons Attribution license (http://creativecommons.org/licenses/by/3.0/). 